Tsaqofiya : Jurnal Pendidikan Bahasa dan Sastra Arab

Vol. 4 No. 1 Januari 2022, 94-112

P-ISSN : 2685-7022, E-ISSN : 2685-7103

DOI: $10.21154 /$ tsaqofiya.v4i1.89

\title{
Urgensi Ilmu dan Akhlak Dalam Syair Al-'Ilm Karya Ma'ruf Al-Rasafi (Kajian Semiotika Michael Riffaterre)
}

\author{
Amaliya Miftahul Ma'arifah', Rohmat² \\ ${ }^{1,2}$ Universitas Islam Negeri (UIN) Sayyid Ali Rahmatullah Tulungagung \\ amaliyamiftahul@gmail.com
}

\section{Abstract}

The purpose of this research is to know about the urgency of knowledge and moral that are carried by Ma'ruf Al-Rasafi in his poem called "Al-'Ilm". This research uses the theory of semiotic by Michael Riffaterre. In his theory, there are two processes of reading, that are heuristic reading or first reading process and hermeneutic reading or second reading process. The method of this research is descriptive-qualitative with a semiotic approach. The results of this research include heuristic reading, hermeneutic reading, matrix, model, and hipogram/intertextual relationship, and the urgency of knowledge and morality. Those resutlts are: (1) Heuristic reading of this poem describes that knowledge can bring to be successful and glorious if it got with sincerity. (2) Hermeneutic reading of this poem is about knowledge that got by sincerity with true methods and can be used in true ways too. The matrix of this poem is about "excellence of knowledge and the way to reach it", with two models; first sentence is "wa inna lil 'ilmi fi al-'ulā falakān" (The knowledge is high above the sky) and second sentence is "wa kullu al-ma'āli tadūru fi qutubihi" (and all the great surrounds the poles). Intertextual relationship of this poem is there are some similarities with a poem by Imam Asy-Syafii, a poem by Amru bin Al-Wardi, and a word of wisdom. (3) The urgency of knowledge and moral that contained in this poem is to be able to have and use knowledge in the right method and way, so they can achieve success and glory by providing benefits to those around them.

Keywords: knowledge and moral, poem Al-'Ilm by Ma'ruf Al-Rasafi, semiotic of Michael Riffaterre

\section{Abstrak}

Tujuan dari penelitian ini adalah untuk mengetahui urgensi ilmu dan akhlak yang diusung oleh Ma'ruf Al-Rasafi di dalam syairnya yang berjudul "Al-Ilmu". Penelitian ini dilakukan dengan menggunakan teori semiotika Michael Riffaterre. Dalam teori semiotika Riffaterre tersebut terdapat dua proses pembacaan yang harus dilakukan, yaitu pembacaan heuristik atau pembacaan tahap pertama dan pembacaan hermeneutik atau pembacaan tahap kedua. Metode yang digunakan dalam penelitian ini adalah deskriptif-kualitatif dengan pendekatan semiotika. Adapun hasil yang diperoleh dari penelitian ini yaitu berupa pembacaan heuristik, pembacaan hermeneutik, matriks, model, dan hipogram yang berupa hubungan intertekstual, serta urgensi ilmu dan akhlak itu sendiri. Masing-masing hasil tersebut, antara lain yaitu: (1) Pembacaan heuristik dari syair tersebut menjelaskan jika ilmu dapat membawa pada kesuksesan dan kemuliaan jika dituntut dengan kesungguhan yang kuat. (2) Pembacaan hermeneutik yang diperoleh adalah tentang ilmu yang dicari dengan usaha yang sungguh-sungguh melalui cara yang benar dan dapat memanfaatkannya di jalan yang benar pula. Matriks dalam syair tersebut adalah tentang "keutamaan ilmu dan jalan untuk menggapainya", dengan dua model yang diperoleh yaitu kalimat "wa inna lil 'ilmi fì al-'ulā falakān" (ilmu berada tinggi di atas bintang) dan kalimat "wa kullu al-ma'āli tadūru fi qutubihi" (setiap yang 
mulia mengeliligi kutubnya). Hubungan interktekstual yang diperoleh, yaitu adanya kesamaan dengan syair Imam Asy-Syafii, syair Amru bin Al-Wardi, dan sebuah kalimat hikmah atau kata-kata mutiara. (3) Urgensi ilmu dan akhlak yang terdapat dalam syair tersebut adalah anjuran untuk dapat memiliki sekaligus menggunakan keilmuan dengan cara dan jalan yang benar, sehingga dapat mencapai kesuksesan dan kemuliaan dengan memberi kebermanfaatan bagi sekitarnya.

Kata Kunci: ilmu dan akhlak, syair Al-'Ilm Ma'ruf Al-Rasafi, semiotika Michael Riffaterre

\section{PENDAHULUAN}

Syair atau puisi sebagai salah satu bagian dari karya sastra, merupakan suatu karya yang tercipta sebagai ungkapan ekspresi pengarang dan bersifat imajinatif dengan keindahan bahasanya yang kuat serta sarat akan kedalaman makna. Sebagaimana pendapat Juzif al-Hasyim yang memberi pengertian modern tentang sastra, menurutnya sastra merupakan ungkapan puitis hasil pemikiran manusia mengenai berbagai pengalaman yang dialaminya dengan bahasa sebagai sarananya. Intinya, sastra merupakan seni ungkapan yang indah. ${ }^{1}$ Syair merupakan salah satu jenis karya sastra Arab tertua yang telah mengalami berbagai perkembangan. Dimulai sejak zaman jahiliyah, yang identik dengan gaya konvensinya yang melekat, hingga berkembang sampai zaman kontemporer dengan gaya kepenulisan yang lebih bebas. ${ }^{2}$ Namun demikian, masih banyak penyair modern yang menggunakan konvensi syair klasik dalam membuat karyanya.

Demikian halnya dengan salah satu penyair yang terkenal kontroversial dalam dunia sastra Irak modern, Ma'ruf Al-Rasafi yang juga masih mempertahankan gaya kepenulisan klasik pada karya sastranya. Ia lahir pada tahun 1875 dan wafat pada tahun $1945 .{ }^{3}$ Ada pula sumber lain yang menyebutkan jika ia lahir pada 1 Januari 1877 dan meninggal pada 16 Maret $1945 .{ }^{4}$ Dikenal sebagai maestro para penyair Timur Tengah di era modern sekaligus masyhur dengan sebutan "penyair kebebasan", karena hampir seluruh syairnya menggambarkan sikap yang kritis terhadap

\footnotetext{
${ }^{1}$ H. Wildana Wargadinata, Laily Fitriani, Sastra Arab dan Lintas Budaya, (Malang: UIN-Malang Press, 2008), hal. 19-20.

2 Eko Adhi Sumariyanto, "Nilai Moral Dalam Novel Al-Ajniḥah Al-Mutakassiroh Karya Kahlil Gibran Dan Memang Jodoh Karya Marah Rusli," Tsaqofiya: Jurnal Pendidikan Bahasa Dan Sastra Arab 2, no. 2 (2020): 84-107.

3 Maryana, Ma'na Syi'ru asy-Syaithān wa at-Thilyān Li Ma'rūf al-Rașāfĩ (Dirāsah Sìmiyāiyyah), (Skripsi, UIN AR-Raniry, 2018), hal. 2.

4 Yasin T. Al-Jibouri, Two Baghdadi Poets, One from Rusafa, One from Karkh, (Iraqi Ministry of Culture, Vol. XXIX, 2013), hal. 2.
} 
pemerintah Irak dan dengan tegas memperjuangkan hak-hak dan keadilan bagi kaum lemah, terutama perempuan. ${ }^{5}$

Al-Rasafi terkenal sebagai penyair, politikus, sekaligus pendidik atau sarjana sastra di Irak. Ia juga dikenal sebagai tokoh yang kontroversial dalam dunia sastra Irak modern karena keberaniannya menentang imperialisme dan membela kebebasan. Banyak dari karyanya yang dilatarbelakangi oleh isu-isu sosial masyarakat dan politik Timur Tengah, khususnya di Irak. Gaya berpuisinya dicirikan dengan penggunaan bahasa yang kuat dan jernih. Menurut Falih al-Hajiya, syair AlRasafi memiliki ciri dengan diksi yang mudah namun penuh keluhuran dan kebanyakan diwarnai dengan isu politik. ${ }^{6}$

Syair Al-'Ilm menjadi salah satu syair yang dibuat oleh Ma'ruf Al-Rasafi. Syair ini merupakan salah satu bagian dalam diwan karangannya. Dalam diwan itu pula ia mengangkat berbagai tema; kosmos, agama, filsafat, perang, pidato, sejarah, politik, dan wanita. ${ }^{7}$ Terlebih, seluruh syair di dalamnya memiliki bentuk yang masih lekat dengan konvensi klasik. Al-Rasafi tidak hanya menjadi penyair, sebagai pendidik yang sangat peduli dengan dunia pendidikan, ia juga menulis banyak buku, seperti di antaranya: Tamāim al-Tarbiyyah wa al-Ta'līm, Durūs fì al-Tārīḥ al-Lugah al'Arabiyyah, Al-Anāsyid al-Madrasiyyah, Muhādarāt al-Adab al-Arabīy, Rasāil alTālìqāt ${ }^{8}$, dan masih banyak lainnya.

Al-Rasafi pernah mengajar di sebuah Institusi di Yerusalem pada sekitar akhir 1919 atau awal 1920. Tidak ada catatan pasti berapa lama ia tinggal di sana, namun dapat diperkirakan jika ia tinggal selama sekitar 18 bulan. ${ }^{9}$ Masa tinggalnya tidak lama dan disertai berbagai konflik politik yang terjadi saat itu. Namun, melalui syair Al-'Ilm membuktikan jika Al-Rasafi tetap produktif dan teguh pada jati dirinya, yang mana ia menuliskan nasihat untuk para pemuda yang sedang menuntut ilmu di Yerusalem saat itu. Syair tersebut sarat akan nasehat tentang keilmuan. Sebagaimana yang terlihat dari latar belakang Al-Rasafi, dapat dipastikan jika kepeduliaannya terhadap dunia keilmuan amatlah besar.

Ilmu dan akhlak merupakan dua hal yang saling berkaitan. Keduanya memiliki peranan penting dalam kehidupan. Sebagaimana ungkapan yang disampaikan oleh

\footnotetext{
${ }^{5}$ Yasin T. Al-Jibouri, Two Baghdadi Poets,..., hal. 4.

${ }^{6}$ Yasin T. Al-Jibouri, Two Baghdadi Poets....., hal. 2.

7 Yasin T. Al-Jibouri, Two Baghdadi Poets....., hal. 3.

${ }^{8}$ Maryana, Ma'na Syi'ru....., hal. 13-14.

${ }^{9}$ Safa Khulusi, Ma'ruf Ar-Rusafi in Jerusalem, (1933), hal. 68.
} 
Abu Zakaria An-Nabari RA, "ilmu tanpa adab (akhlak) seperti api tanpa kayu bakar, dan adab (akhlak) tanpa ilmu seperti jasad tanpa ruh". Urgensitas keduanya menunjukkan jika setiap manusia memiliki tanggung jawab untuk menuntut ilmu dan memperbaiki akhlaknya. Maka dengan begitu, mereka dapat hidup dengan baik dan benar sesuai dengan ilmu dan akhlak yang ditanamkan dalam diri lalu diimplementasikan dalam kehidupan.

Dalam penelitian ini, peneliti akan mengungkapkan makna tentang pentingnya ilmu dan akhlak dalam syair Al-'Ilm karya Ma'ruf Al-Rasafi melalui teori semiotika Michael Riffaterre. Teori tersebut sejalan dengan tujuan penelitian, yakni untuk menelaah bahasa pada puisi yang mengandung makna tersirat. Melalui penelitian ini, diharapkan dapat menambah kazanah dalam literatur kesusastraan dan menjadi referensi dalam melakukan penelitian yang sejenis, baik syair, tokoh/penyair, maupun teori yang diusung.

\section{TEORI SEMIOTIKA MICHAEL RIFFATERRE}

Semiotika secara umum merupakan suatu ilmu yang mempelajari atau mengkaji tanda dan simbol. Adapun definisi tanda dalam Kamus Besar Bahasa Indonesia (KBBI) meliputi: (1) yang menjadi alamat atau yang menyatakan sesuatu, (2) gejala, (3) bukti, (4) pengenal; lambang, dan (5) petunjuk. Saussure, sebagai Bapak semiotika modern menegaskan jika bahasa sebagai tanda atau sistem tanda yang mengekspresikan gagasan. ${ }^{10}$ Semiotika memiliki dua manfaat dasar sebagaimana diungkapkan oleh Art van Zoest, yaitu manfaat teoretis yang meggunakan semiotika sebagai alat bantu untuk merumuskan teori-teori semiotika dan manfaat praktis yang mana semiotika telah diterapkan dalam bidang-bidang tertentu sehingga dapat dimanfaatkan oleh kalangan umum. ${ }^{11}$

Riffaterre mencetuskan teori semiotika khusus puisi karena tidak setuju dengan teori yang diusung oleh Jakobson. Menurut Jakobson, dalam menganalisis hanya perlu memperhatikan aspek kebahasaan atau linguistik dengan pengertian yang terbatas serta mengabaikan aspek yang lainnya. Sehingga Riffaterre melahirkan teori ini atas dasar jika dalam menganalisis juga diperlukan aspek lainnya, seperti aspek pragmatik dan ekspresif yang dapat mengungkap peran pembaca dan penulis. hal. 3 .

10 Wildan Taufiq, Semiotika untuk Kajian Sastra dan Alquran, (Bandung: Yrama Widya, 2016),

\footnotetext{
11 Wildan Taufiq, Semiotika untuk Kajian....., hal. 4.
} 
Riffaterre juga berpendapat jika karya puisi bukan hanya sebatas tata bahasa, melainkan lebih dari pada itu. Akan tetapi analisis gramatikal yang dilakukan pada bahasa puisi tidak dapat memberikan lebih daripada gramatika suatu puisi itu sendiri. ${ }^{12}$

Menurut Riffaterre, bahasa puisi memiliki perbedaan dengan bahasa yang digunakan dalam keseharian. Di dalam puisi, bahasa yang digunakan menyebutkan adanya ketidaklangsungan ekspresi. ${ }^{13}$ Sebagaimana pendapatnya pula jika bahasa puisi menyebutkan satu hal dan memaksudkan hal yang lain, ia memiliki pandangan jika perbedaan yang tertangkap secara empiris di antara puisi dan non-puisi sepenuhnya dijelaskan oleh bagaimana suatu teks yang bernilai puitik itu membawa makna. ${ }^{14}$ Maka, ia mengusung dua tahap pembacaan yang dapat menganalisis aspek linguistik dan aspek sastra terhadap bahasa puisi, yaitu pembacaan heuristik dan hermeneutik.

\section{Pembacaan Heuristik}

Pembacaan heuristik disebut juga sebagai pembacaan tahap pertama dengan melakukan pembacaan secara berurutan dari awal hingga akhir, dari setiap kata, frasa, klausa, dan kalimat yang tersebar dengan memperhatikan tata bahasa atau struktur kebahasaannya, atau berdasarkan sistem semiotika tingkat pertama. ${ }^{15}$ Maka dapat dikatakan jika pembacaan ini bersifat mimetik, karena melibatkan kompetensi linguistik pembaca. ${ }^{16}$ Dalam tahap ini akan ditemukan kata atau kalimat yang tidak sesuai gramatikal atau bersifat ungramatikal, terpecah-pecah, terdapat heterogenitas makna, dan ambiguitas ${ }^{17}$ sehingga diberi kata yang dapat memperjelas arti baik berupa sisipan atau sinonim apabila diperlukan. ${ }^{18}$

\section{Pembacaan Hermeneutik}

Pembacaan hermeneutik atau disebut juga pembacaan retroaktif merupakan pembacaan tahap kedua atau pembacaan ulang dengan lebih

\footnotetext{
12 Wildan Taufiq, Semiotika untuk Kajian....., hal. 120.

13 Jafar Lantowa, dkk, Semiotika; Teori, Metode, dan Penerapannya dalam Penelitian Sastra, (Yogyakarta: Deepublish, 2017), hal. 9.

14 Jafar Lantowa, dkk, Semiotika; Teori....., hal. 9.

15 Wildan Taufiq, Semiotika untuk Kajian....., hal. 132.

16 Jafar Lantowa, dkk, Semiotika; Teori...., hal. 11.

17 Jafar Lantowa, dkk, Semiotika; Teori...., hal. 20.

18 Rachmat Djoko Pradopo, Beberapa Teori Sastra, Metode Kritik, dan Penerapannya, (Yogyakarta: Pustaka Pelajar, 2012), hal. 136.
} 
memperhatikan konvensi sastranya, atau disebut sistem semiotika tingkat kedua. ${ }^{19}$ Pembacaan hermeneutik ini juga disebut sebagai interpretasi yang sesungguhnya. Dari tahap pembacaan ini akan diperoleh kesatuan makna. Pada tahap ini pula terdapat kompetensi kesusastraan pembaca yang kemudian mampu menginterpretasikan hasil dari yang telah dibaca pada tahap pembacaan pertama. Melalui pembacaan ulang ini pula, akan ditemukan beberapa hal pendukung yang juga dapat menguatkan hasil dari pembacaan kedua tersebut, di antaranya adalah matriks dan model, serta hipogram.

\section{a. Matriks}

Matriks disebut juga sebagai penggerak atau generator, yaitu berupa suatu kata, gabungan kata, bagian kalimat, atau kalimat sederhana yang bersifat hipotesis sebagai aktualisasi dari struktur teks. Menurut Riffaterre, suatu teks diibaratkan sebagai sebuah donat, yang mana bagian tengah yang berlubang memiliki peran sebagai penopang keseluruhan donat. Lubang yang kosong ini nyatanya tidak ada namun dapat berfungsi sebagai identifikasi bagaimana donat itu dikenal sebagai donat. Lubang itu ia analogikan sebagai matriks, sedangkan bagian daging donatnya merupakan keseluruhan makna teks. ${ }^{20}$ Matriks ini kemudian berkembang menjadi model, yang berperan sebagai aktualisasi primer atau aktualisasi pertama dari matriks.

\section{b. Hipogram}

Adapun hipogram pada dasarnya merupakan latar penciptaan suatu karya sastra, yang meliputi keadaan sosial masyarakat, peristiwa dalam sejarah atau peristiwa alam, dan latar kehidupan yang dialami oleh penyair. Hipogram dapat dihasilkan melalui teks-teks lain yang disejajarkan atau dibandingkan dengan teks yang diteliti sehingga dapat diketahui hubungannya, yang kemudian dapat lebih mudah mengungkap signifikansi teks. ${ }^{21} \mathrm{Hal}$ ini biasa disebut sebagai hubungan intertekstual.

\section{METODE PENELITIAN}

Bentuk penelitian ini adalah deskriptif-kualitatif dengan pendekatan semiotika Michael Riffaterre. Hal ini disesuaikan dengan tujuan dari penelitian ini, yaitu untuk

${ }^{19}$ Rachmat Djoko Pradopo, Beberapa Teori Sastra....., hal. 137.

20 Jafar Lantowa, dkk, Semiotika; Teori....., hal. 19.

21 Jafar Lantowa, dkk, Semiotika; Teori....., hal. 16-17. 
mendeskripsikan sekaligus menganalisis bentuk-bentuk semiotika; matriks, model, dan hipogram yang terkandung di dalam syair Al-'Ilm karya Ma'ruf Al-Rasafi, serta mendeskripsikan urgensi ilmu dan akhlak di dalam syair tersebut. Data penelitian yang diperoleh berbentuk data kepustakaan dan menerapkan teknik telaah atau studi pustaka dalam melakukan penelitian. Sedangkan untuk langkah kerja penelitian yang digunakan, disesuaikan dengan langkah yang telah dijelaskan oleh Riffaterre, yaitu melalui dua tahap pembacaan, pembacaan heuristik dan pembacaan hermeneutik. Langkah tersebut sekaligus sebagai metode untuk menganalisis serta mendeskripsikan makna syair Al-'Ilm karya Ma'ruf Al-Rasafi tersebut. Sehingga makna terdalam di dalam syair tersebut dapat tersampaikan dengan baik. Melalui pembacaan heuristik akan melihat struktur kebahasaan yang terdapat dalam syair, sehingga ditemukan kata atau kalimat yang perlu diberi penjelasan. Sedangkan melalui pembacaan hermeneutik, akan ditemukan makna sesungguhnya dari syair dengan menganalisis struktur sastranya, sehingga juga menghasilkan matriks, model, dan hipogram/hubungan intertekstual.

\section{PEMBAHASAN}

Syair Al-'Ilm karya Al-Rasafi ini merupakan salah satu syair yang terdapat di dalam Dīwān Ma'ruf Al-Rașāfì dengan revisi oleh Mustafa Al-Ghalaini yang secara utuh terdiri atas 35 bait. Namun, peneliti hanya mengambil 10 bait pertama syair tersebut untuk dijadikan objek material dalam penelitian ini.
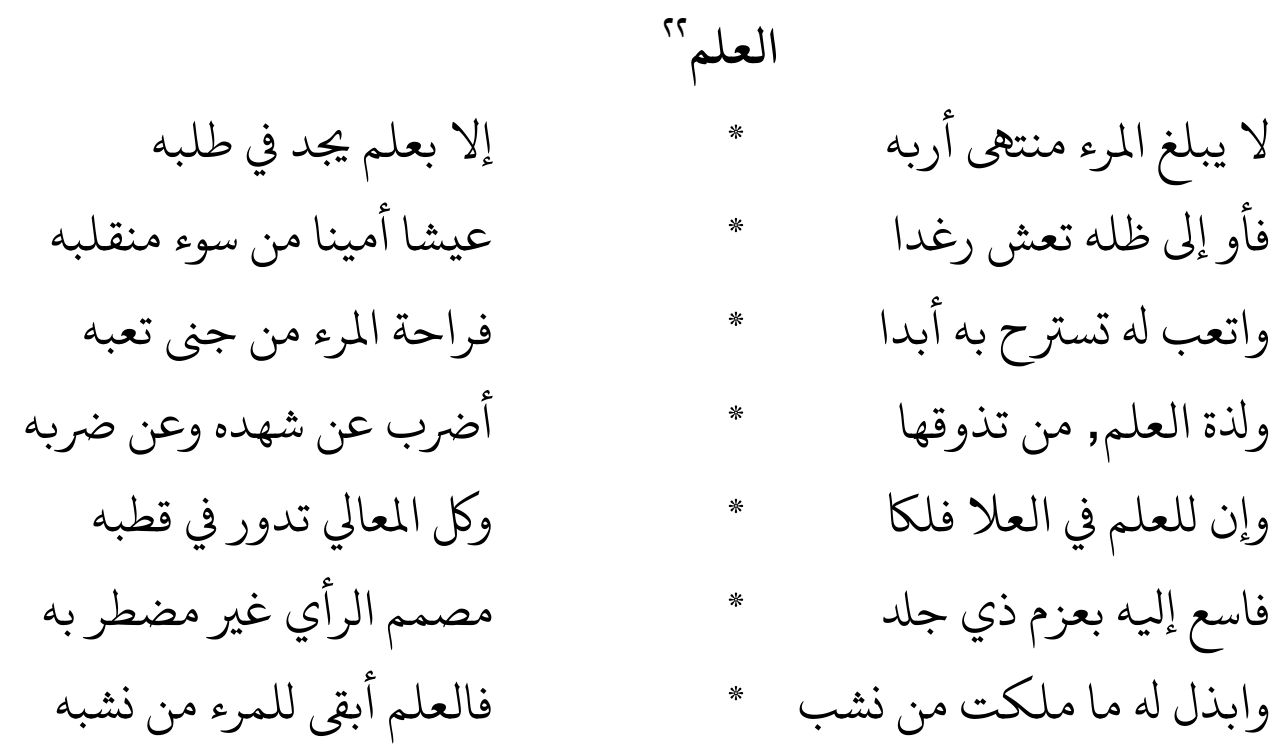

${ }^{22}$ Ma'ruf Al-Rasafi, Dīwān Ma'rūf Al-Rașāfì, (Kairo: Hindawi, 2012), hal. 141. 

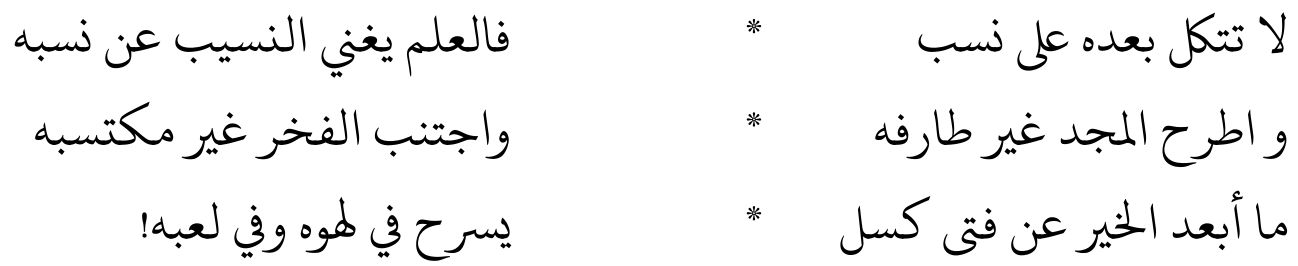

\section{Ilmu}

(1) Seseorang tak akan mencapai puncak kesuksesannya \# Kecuali dengan ilmu yang ia tuntut dengan kesungguhan kuat

(2) Maka berteduhlah dalam naungannya, kau akan hidup dalam kedamaian \# Hidup aman dari keburukan yang merusaknya

(3) Bersusahpayahlah menuntut ilmu, kau akan tenang selamanya \# Ketenangan seseorang bagian dari buah keletihannya

(4) Kelezatan ilmu bagi siapa pun yang menikmatinya \# Menjadikannya bukti atas usaha kerasnya

(5) Ilmu berada tinggi di atas bintang \# Setiap yang mulia mengelilingi kutubnya

(6) Berusahalah mencapainya dengan semangat orang yang sabar \# Menetapkan pikiran tanpa memaksakannya

(7) Bersusahpayahlah untuk mencapainya hingga ia mengakar kuat \# Ilmu lebih abadi bagi seseorang daripada nasab

(8) Janganlah bergantung pada nasab setelahnya \# Ilmu memperkaya kerabat daripada nasab

(9) Jauhilah kemuliaan yang tak dicapainya \# Buanglah kehormatan yang tak pada jalannya

(10) Sungguh, kesuksesan sangat jauh dari pemuda yang malas \# Yang merasa senang dalam kelalaian dan permainannya

\section{Pembacaan Heuristik Syair Al-'Ilm}

\section{Ilmu}

(1) Seseorang tak akan mencapai (memperoleh) puncak (tingkatan tertinggi/teratas) kesuksesan (keberhasilan) nya \# Kecuali (ia berusaha) dengan ilmu yang ia tuntut dengan kesungguhan (yang) kuat.

(2) Maka berteduh (berlindung) lah dalam naungannya (ilmu), (dengan begitu) kau akan hidup dalam kedamaian (tanpa rasa cemas) \# (Yaitu) Hidup aman dari keburukan (kesulitan) yang merusaknya (kehidupan). 
(3) Bersusahpayahlah (dalam) menuntut ilmu, (maka) kau akan (dapat beristirahat dengan) tenang selamanya (karena telah memiliki ilmu) \# (Karena) Ketenangan (bagi) seseorang (adalah) bagian dari buah (hasil) keletihannya (dalam menuntut ilmu).

(4) Kelezatan (nikmat) ilmu (dapat dirasakan) bagi siapa pun yang menikmatinya (memetik hasilnya) \# Menjadikannya (sebagai) bukti atas usaha kerasnya (kesusahpayahannya).

(5) Ilmu berada tinggi di atas (seperti) bintang \# Setiap yang mulia (kebaikankebaikan/orang yang gemar menuntut ilmu) mengelilingi kutubnya (sisinya).

(6) Berusahalah mencapainya (ilmu) dengan semangat (seperti yang dimiliki) orang yang sabar \# (Yaitu dengan) Menetapkan pikiran (teguh) tanpa memaksakannya (memahami kapasitas kemampuannya).

(7) Bersusahpayahlah untuk mencapainya (ilmu) hingga ia (ilmu) mengakar kuat (dalam diri) \# (Karena) Ilmu lebih abadi bagi seseorang daripada nasab (garis keturunan).

(8) Janganlah bergantung pada nasab (garis keturunan) setelahnya (ilmu) \# (Karena) Ilmu (dapat lebih) memperkaya kerabat (sanak keluarga) daripada nasab.

(9) Hindarilah (mencari) kemuliaan (yang diperoleh) bukan pada jalannya (cara yang tidak benar) \# Buanglah (jauhilah mencari) kehormatan yang tak diperolehnya (dengan semestinya).

(10) Sungguh, sangat jauh (jarak antara) kebaikan (kesuksesan) dari pemuda yang malas \# (Pemuda) Yang merasa senang dalam kelalaian (keburukan) dan permainannya (bersantai/bermalas-malas).

Dari pembacaan ini, dapat dilihat jika terdapat banyak kata yang memiliki heterogenitas makna, mengalami ambiguitas, dan ungramatikal. Di antara kata yang memiliki heterogenitas makna yaitu: (bait ke-1) memperoleh dan kesuksesan, (bait ke-2) berteduh, kedamaian, dan keburukan, (bait ke-3) buah, (bait ke-4) nikmat dan usaha keras, (bait ke-5) kutub, (bait ke-7) nasab, (bait ke8) nasab dan kerabat, dan (bait ke-10) kebaikan dan keburukan.

Adapun kata atau kalimat yang mengalami ambiguitas di antaranya adalah: (Bait ke-1) 'puncak kesuksesan' yang tidak pasti batasannya dapat diartikan 
tingkatan tertinggi keberhasilan bagi setiap orang. (Bait ke-3) 'kau akan tenang selamanya' berarti dapat tenang dalam beristirahat setelah mencari ilmu. (Bait ke-4) kata 'menikmatinya' bermaksud memetik hasil dari ilmu yang diperoleh. (Bait ke-5) 'di atas bintang' berarti ilmu memiliki derajat yang tinggi seperti bintang, dan 'yang mulia' dimaksudkan untuk orang yang gemar menuntut ilmu yang dapat juga berarti kebaikan.

(Bait ke-6) 'semangat orang sabar' berarti semangat yang seperti dimiliki orang yang sabar, dan 'menetapkan pikiran tanpa memaksakannya' dimaksudkan pada semangat orang sabar yang tetap teguh pada pikirannya namun tidak memaksakan kapasitas kemampuannya. (Bait ke-9) 'buanglah' berarti jauhilah, 'kehormatan yang tak diperolehnya' memiliki maksud suatu kehormatan yang tidak ia peroleh dengan semestinya/cara yang buruk, dan 'bukan pada jalannya' berarti cara yang tidak benar. (Bait ke-10) 'sangat jauh kebaikan' berarti jika sangat jauh jarak antara kebaikan dengan pemuda yang malas, dan 'permainannya' berarti sikap bersantai yang cenderung bermalas-malasan.

Sedangkan kata atau kalimat yang mengalami ungramatikal lebih mengarah pada kurangnya kata hubung dan kata penjelas antar kata atau kalimat yang menyebabkan kalimat-kalimat tersebut kurang dapat dipahami. Di antaranya yaitu: (Bait ke-1) kecuali 'ia berusaha' dengan ilmu... dan seterusnya. (Bait ke-2) maka berteduhlah dalam naungannya 'dengan begitu' kau akan hidup dalam kedamaian, 'yaitu' hidup aman... dan seterusnya. (Bait ke-3) ...bagian dari buah keletihannya 'dalam menuntut ilmu'. (Bait ke-4) ...ilmu 'dapat dirasakan' bagi siapapun yang memetiknya, menjadikannya 'sebagai' bukti... dan seterusnya.

(Bait ke-6) ...dengan semangat orang sabar 'yaitu dengan' menetapkan pikiran... dan seterusnya. (Bait ke-7) ...hingga ia mengakar kuat 'dalam diri' 'karena' ilmu lebih abadi... dan seterusnya. (Bait ke-8) janganlah bergantung pada nasab setelahnya 'ilmu' 'karena' ilmu 'dapat lebih' memperkaya kerabat... dan seterusnya. (Bait ke-9) hindarilah kemuliaan 'yang diperoleh' bukan pada jalannya. (Bait ke-10) 'pemuda' yang merasa senang dalam kelalaian.

\section{Pembacaan Hermeneutik Syair Al-'Ilm}

Bait pertama ini menjelaskan orang yang benar-benar sampai di puncak kesuksesan adalah orang yang telah melewati pahit dan susahnya jalan menuntut 
ilmu. Hal ini terlihat dalam pola susunan kalimat "kecuali dengan ilmu yang dituntut dengan kesungguhan". Orang yang memiliki semangat kuat dan kesungguhan dalam menuntut ilmu pasti dapat mencapai kesuksesan dalam hidupnya. Kesuksesan setiap orang memiliki tingkat ketinggian yang berbedabeda. Namun, dengan ilmu yang dimilikinya, hidupnya sudah terjamin akan dalam kebaikan.

Pada bait kedua ini terdapat kata berupa fiil amr, yaitu fa'wi yang berasal dari kata $\bar{a} w \bar{a}$ yang memiliki arti memberikan perlindungan, atau memberi tempat bernaung. ${ }^{23}$ Maka dalam hal ini, ilmu dianggap berperan sebagai pelindung dalam kehidupan. Hal ini ditegaskan dengan adanya dua kata yang beriringan dalam satu bait, yaitu ragadān dan amīnān yang berarti damai dan aman. Bernaung atau berlindung dalam naungan ilmu, berarti mendalami ilmu dan selalu menggunakannya dalam setiap tindakannya. Sehingga ia akan hidup dalam kedamaian, rasa aman, dan ketentraman.

Pada bait ketiga ini, menjelaskan bentuk kesungguhan yang terdapat dalam bait pertama, dengan adanya kata it'ab yang berarti bersusahpayah. Dalam menuntut ilmu, hendaknya dilakukan dengan usaha yang maksimal, tidak selalu dengan kemudahan. Dengan mengalami beberapa kesulitan dalam menuntut ilmu agar dapat lebih menghargainya sehingga dapat memanfaatkannya dengan benar. Sehingga nantinya, ilmu itu dapat membuatnya beristirahat dengan tenang karena menikmati hasil dari kesusahpayahannya.

Bait keempat, terdapat metafora pada kata kelezatan atau kenikmatan yang berarti bahwa kenikmatan dalam memiliki ilmu dapat lebih dirasakan bagi mereka yang telah menuntut ilmu dengan usaha yang keras, seperti ungkapan "terbentur lalu terbentuk". Dalam bait ini pula ditegaskan jika kenikmatan ilmu diibaratkan seperti orang yang menikmati makanan karena rasa syukur dan kelaparan dengan penggunaan kata lażżatun. Dapat mengaplikasikan ilmu yang dimiliki dalam jalan kebenaran merupakan bentuk kenikmatan yang diperoleh oleh orang yang berilmu.

Pada bait kelima ini terdapat metafora dalam kata al-'ulā yang berarti tinggi ${ }^{24}$ menjelaskan tentang keagungan, yaitu keagungan ilmu yang diandaikan seperti

${ }^{23}$ Kamus Al-Ma'ānīy Arab Indonesia, (diakses pada tanggal 6 Februari 2021)

${ }^{24}$ Kamus Al-Ma'ānīy Arab Indonesia, (diakses pada tanggal 6 Februari 2021) 
bintang yang berada tinggi di langit. Kata al-ma'ālī atau yang berarti 'yang mulia' pada bait ini merujuk kepada orang-orang yang senang menuntut ilmu, yang kemudian digambarkan bergerumbul mengelilingi setiap kutub atau sisi pada bintang itu.

Pada bait keenam ini, penyair kembali menegaskan untuk berusaha dalam menuntut ilmu dengan penggunaan kata was'a. Menuntut ilmu juga harus dilakukan dengan penuh kesabaran. Dengan tetap teguh namun tanpa memaksakan diri. Memahami jika kemampuan setiap orang berbeda-beda. Kapasitas pemahaman tiap individu juga tidak sama. Hal ini menunjukkan jika kita harus bijaksana terhadap diri sendiri.

Pada bait ketujuh ini terdapat metafora dalam kata ubżul yang berarti berusaha keras, mengorbankan ${ }^{25}$, mengandung makna bahwa memperjuangkan ilmu hingga dapat dipahami secara mendalam dan melekat kuat dalam hati dapat lebih abadi daripada nasab atau keturunan.

Bait kedelapan ini masih berkesinambungan dengan bait ketujuh, menjelaskan jika tidak perlu terlalu bergantung pada nasab. Karena dengan ilmu, seseorang dapat memiliki lebih banyak kerabat dengan wawasan yang luas dan mempertemukan dengan orang-orang dengan berbagai latar belakang. Hal ini berarti orang yang berilmu dapat mengandalkan ilmunya, ia tidak perlu bergantung pada kerabat hanya karena menginginkan suatu jabatan.

Bait kesembilan, menjelaskan bagaimana seharusnya menggunakan ilmu yang dimiliki, yaitu dilarang untuk mencari kemuliaan dan kehormatan melalui jalan yang salah. Hal ini menegaskan jika ilmu juga harus diiringi dengan akhlak. Agar dapat menggunakan ilmu dalam kebaikan, sesuai anjuran agama dan tidak menyalahgunakannya untuk memperoleh jabatan atau kekuasaan dengan cara yang salah.

Bait kesepuluh, terdapat metafora pada kata al-khaira yang memiliki arti kebaikan ${ }^{26}$ merujuk pada makna kesuksesan yang hanya dapat diperoleh dengan usaha yang sungguh-sungguh. Metafora berikutnya juga terdapat dalam kata yasrậu yang berarti beristirahat ${ }^{27}$, mengandung makna bersantai yang lebih

${ }^{25}$ Kamus Al-Ma'ānīy Arab Indonesia, (diakses pada tanggal 6 Februari 2021)

${ }^{26}$ Kamus Al-Ma'ānīy Arab Indonesia, (diakses pada tanggal 6 Februari 2021)

${ }^{27}$ Kamus Al-Ma'ānīy Arab Indonesia, (diakses pada tanggal 6 Februari 2021) 
mengarah pada kemalasan, serta kata lahwi yang berarti permainan ${ }^{28}$, mengandung makna kelalaian. Maka dalam bait ini menjelaskan jika seorang pemuda yang hanya gemar bermalas-malasan dan terlalu terlena dalam kesenangan sesaat akan berada jauh dari kesuksesannya.

Dari keseluruhan bait tersebut, dapat dilihat Al-Rasafi berulangkali menegaskan agar berusaha, bersungguh-sungguh, dan bersusahpayah dalam menuntut ilmu. Adapula akhlak, Al-Rasafi juga menegaskan untuk menjauhi perbuatan malas yang merupakan penyakit hati, serta menghindari cara yang salah dalam mendapatkan jabatan atau kehormatan, karena dapat merusak nilai dari ilmu itu sendiri. Nasihat ini ia tujukan kepada para pemuda. Hal ini menunjukkan jika ia sangat peduli terhadap generasi penerus agar dapat memberikan manfaat bagi sekitarnya hingga kemudian dapat berimbas bagi kebaikan masa depan generasi mereka.

\section{a. Matriks dan Model}

Setelah melakukan pembacaan hermeneutik, maka akan ditemukan matriks atau kerangka utama dari syair tersebut. Adapun matriks dari syair Al'Ilm adalah "keutamaan ilmu dan jalan untuk menggapainya". Terdapat dua model yang menjadi aktualisasi primer dalam syair tersebut. Dua model tersebut berupa kalimat yang bernilai puitis yang terdapat dalam satu bait, yaitu kalimat "Wa inna lil 'ilmi fì al-ulā falakān" yang berarti "ilmu berada tinggi di atas bintang” dan kalimat “Wa kullu al-ma'āli tadūru fí qutubihi” yang berarti "setiap yang mulia mengelilingi kutubnya". Bait ini dipilih karena dapat menggambarkan seluruh penjelasan tentang keutamaan ilmu yang terdapat dalam syair tersebut. Ilmu yang diibaratkan berada tinggi di angkasa sudah menegaskan betapa penting dan tinggi derajatnya, sehingga dapat memberi keutamaan-keutamaan bagi yang menggapainya.

\section{b. Hipogram (Hubungan Intertekstual)}

Dalam ajaran Islam, telah banyak dalil yang menjelaskan tentang pentingnya ilmu dan akhlak, baik di dalam Alquran, sunnah, maupun dalam syair hikmah. Salah satu ayat Alquran yang paling masyhur tentang ilmu adalah QS. Al-Mujadilah (58): 11, yang berbunyi sebagai berikut,

\footnotetext{
${ }^{28}$ Kamus Al-Ma'ānīy Arab Indonesia, (diakses pada tanggal 6 Februari 2021)
} 


$$
\begin{aligned}
& \text {.... وإذا قيل انشزوا فانشزوا يرفع الله الذين امنوا منكم ٍِّ والذين اوتوا }
\end{aligned}
$$

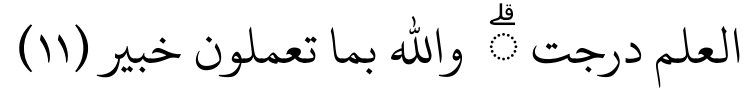

"...Dan apabila dikatakan, "Berdirilah kamu," maka berdirilah, niscaya Allah akan mengangkat (derajat) orang-orang yang beriman di antaramu dan orang-orang yang diberi ilmu beberapa derajat. Dan Allah Maha Teliti apa yang kamu kerjakan." (11)

Syekh Syarafuddin al-Imrithy juga menuliskan nasihat dalam kitab karangannya yang terkenal, kitab Al-Imrițīy. Salah satu bait di dalamnya berbunyi:

$$
\text { كلا ترم علما وتترك التعب }
$$

"Janganlah kamu menginginkan suatu ilmu, sedangkan kamu menghindari kelelahan."

Adapun ungkapan-ungkapan tentang ilmu dan akhlak yang disampaikan oleh ulama atau pujangga. Pemilihan syair dan kalimat mutiara berikut ini selain karena keselarasan tema dengan syair Al-'Ilm, juga karena nilai-nilai yang diangkat adalah yang memiliki kesamaan paling dekat dengan syair Al-'Ilm.

Seperti Imam Asy-Syafii yang juga banyak menuliskan bait-bait hikmah tentang pentingnya ilmu dan menuntut ilmu. Beberapa bait di antaranya adalah sebagai berikut,

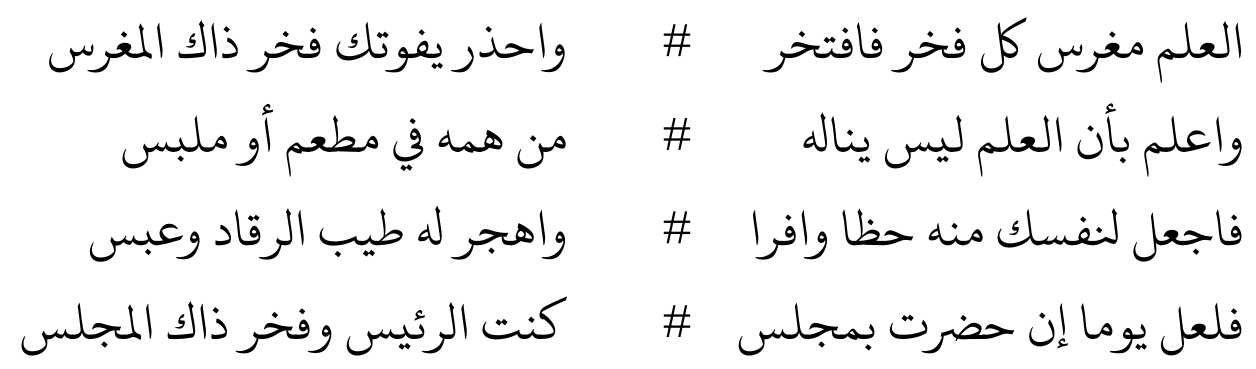

"Ilmu adalah tempat persemaian setiap kemuliaan, maka banggakanlah, dan berhati-hatilah jika tempat persemaian itu tak memunculkan suatu kebanggaan. 
Ketahuilah bahwa ilmu itu tak akan didapat, dari seseorang yang citacita hidupnya hanya demi makanan dan pakaian.

Maka jadikanlah dirimu bagian dari orang yang memiliki peranan tinggi, dan tinggalkanlah pola hidup santai dan sikap acuh tak acuh.

Maka mungkin suatu saat, kau hadir di suatu majelis, sebagai pemimpin dan bintang majelis itu." 29

Bait syair di atas memiliki nilai tentang kemuliaan yang didapatkan bagi yang menuntut ilmu dan menghindari sikap santai yang terkesan berleha-leha dalam hidup. Hal ini selaras dengan syair Al-'Ilm. Selain itu, di dalam syair tersebut disebutkan, 'berhati-hatilah jika tempat persemaian itu tidak melahirkan suatu kebanggaan'. Hal ini berarti jika ilmu juga dapat membawa celaka jika kita tidak melewati jalan yang benar. Sama halnya dengan syair Al-'Ilm yang juga membahas tentang bagaimana akhlak dalam menggunakan ilmu dan menghindari sikap tercela yang dapat merusak ilmu.

Syair lainnya yaitu potongan bait dari syair karya Amru bin Al-Wardi tentang nasihat dalam menuntut ilmu,

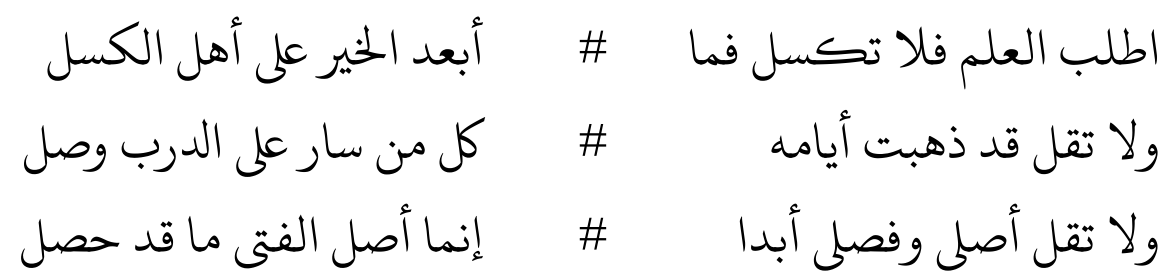

"Tuntutlah ilmu dan jangan bermalas-malasan, Sungguh sangat jauh kesuksesan dari seorang pemalas.

Jangan mengatakan, "Sudah terlambat". Setiap yang berjalan pada jalannya, pasti akan sampai ke tujuan.

Jangan pernah mengatakan, "inilah keluargaku dan kedudukanku," Sungguh, kedudukan pemuda tercermin dari karyanya."30

Dari bait syair di atas juga berkaitan dengan syair Al-'Ilm karya AlRasafi, yaitu nilai tentang anjuran untuk menuntut ilmu dengan tidak bermalas-malasan agar dapat mencapai kesuksesan, karena bermalasmalasan merupakan bentuk sikap tercela. Kesamaan lain di antara kedua syair tersebut adalah tentang akhlak, yaitu larangan untuk menghindari 
sikap membanggakan dan bergantung kepada keluarga (nasab), hanya untuk menunjukkan dan memperoleh suatu jabatan.

Terdapat pula sebuah kalimat hikmah atau kata-kata mutiara (mahfuzat) yang berbunyi,

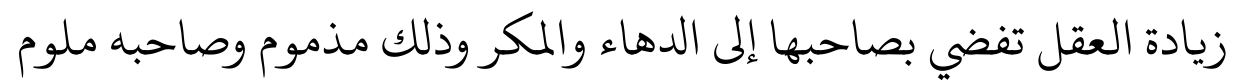

“Bertambahnya kecerdasan mendorong seseorang ke arah kelicikan dan penipuan, yang merupakan sikap tercela serta membuat pelakunya hina." 31

Dalam kalimat hikmah tersebut memberi penjelasan jika kecerdasan dapat membuat seseorang melakukan sikap yang tercela. Hal tersebut selaras dengan nilai dalam syair Al-'Ilm yang juga menjelaskan tentang larangan untuk tidak memperoleh kehormatan atau jabatan melalui yang bukan jalannya. Di antara keduanya memiliki keterkaitan tentang pentingnya untuk membersamai ilmu dengan akhlak yang mulia agar tidak menjadi seorang yang hina.

\section{URGENSI ILMU DAN AKHLAK DALAM SYAIR AL-ILMU}

Setelah melakukan kedua tahap pembacaan terhadap syair Al-'Ilm tersebut, terlihat jelas jika Al-Rasafi menegaskan bahwa ilmu dan akhlak merupakan dua hal yang tidak boleh dipisahkan. Dalam hal ini, betapa pentingnya kita harus mengetahui dan memahami tentang ilmu dan akhlak sesuai yang terdapat dalam syair tersebut. Sejak dalam proses mencari ilmu hingga mengimplementasikan ilmu itu sendiri, perlu adanya peran akhlak sehingga seseorang tidak menyalahgunakan keilmuan mereka dan terjerumus dalam kehinaan.

Terdapat tiga poin yang dapat diambil dari syair tersebut. Poin pertama adalah tentang proses menuntut ilmu yang menurut Al-Rasafi harus dituntut dengan kesungguhan atau semangat yang kuat, kesabaran dan tidak memaksakan diri, bersusahpayah, dan tidak bermalas-malasan atau hanya bermain-main. Adapun poin kedua adalah tentang manfaat yang didapat jika memiliki ilmu, yaitu kesuksesan, ketenangan dan keamanan dalam hidup, serta dapat mengimplementasikannya dalam kehidupan. Sedangkan poin yang ketiga adalah larangan bagi orang yang

\footnotetext{
31 Tim Turos Pustaka, Mahfuzhat....,hal. 115.
} 
berilmu, yaitu tidak menggantungkan nasib kepada nasab atau kerabat dan tidak mencari jabatan atau kehormatan dengan cara yang kotor, serta menjauhi sikap lalai yang juga merupakan perbuatan tercela.

Pada poin pertama, hal itu kurang lebih sesuai dengan etika atau adab menuntut ilmu yang dianjurkan agama. Lalu pada poin kedua, memberikan penjelasan tentang mengambil hikmah. Jika ilmu dituntut tidak hanya untuk diri sendiri, melainkan untuk melayani masyarakat, memberi kebermanfaatan untuk sesama. Selanjutnya pada poin ketiga, memberikan penjelasan jika orang berilmu juga dapat menjumpai godaan, maka A-Rasafi sudah mewanti-wanti untuk menjauhi hal-hal tersebut. Keberadaan akhlak di sini dapat terlihat, karena pasti hanya orang-orang berakhlak yang dapat menyikapi hal tersebut dengan baik.

Tiga poin tersebut pada intinya merupakan bentuk akhlak terhadap diri sendiri yang kemudian juga berimbas terhadap sesama. Ilmu dan akhlak memiliki sinergi untuk saling menopang. Ilmu yang tidak disertai akhlak yang mulia dapat membinasakan pemiliknya. Seperti yang terjadi dewasa ini, semakin bertambah banyak fenomena yang menjadi ciri dari krisis akhlak. Banyak manusia yang jauh dari gambaran khalifah fii al-ardh. Sebagai contoh orang-orang berilmu yang buta akhlak, seperti melakukan korupsi, atau tindakan mengeksploitasi alam secara berlebihan lalu menyebabkan kerusakan alam, dan lain sebagainya.

Jika melihat di masa Al-Rasafi, ia hidup melewati beragam polemik baik sosial maupun politik di negaranya. Ia melihat bagaimana Inggris menduduki Irak tahun 1920, setelah berakhirnya Perang Dunia I, lalu melakukan monopoli dengan membuat konstitusi dan mendirikan parlemen yang menurut Al-Rasafi dan masyarakat Irak lainnya sebagai hal yang palsu. Pemerintah dan rakyat berada di bawah otoritas Inggris saat itu. Sehingga pemerintah yang telah dibutakan tidak lagi mementingkan kesejahteraan rakyat dan menyebabkan terjadinya krisis kebebasan dan keadilan di sana. ${ }^{32}$

Oleh karena itu, dalam dunia politik, Al-Rasafi berpandangan bahwa pengetahuan adalah sesuatu yang harus ditekankan urgensitasnya. Menurutnya, pencari pengetahuan harus mencarinya bukan untuk diri sendiri, tetapi untuk melayani masyarakat. Ia juga menekankan jika mereka harus dapat mengambil manfaat dari

\footnotetext{
32 Yasin T. Al-Jibouri, Two Baghdadi Poets....., hal. 4.
} 
pengetahuannya baik melalui pekerjaan atau setiap tindakan. ${ }^{33}$ Maka, dapat dilihat jika urgensi ilmu atau pengetahuan bagi Al-Rasafi adalah pengetahuan yang dapat memberikan implementasi bagi setiap lini kehidupan.

Dapat dilihat jika sejak masa Al-Rasafi hingga di masa saat ini, masih tetap ada sebagian orang yang menganggap akhlak sebagai hal yang tidak berharga sama sekali, karena telah terkungkung dalam nafsu berupa sikap hedonistis dan materialistis. Pemahaman tentang ilmu dan akhlak perlu untuk ditanamkan kembali. Terutama akhlak yang memiliki peran sebagai tonggak pertama perubahan masyarakat, dan dapat berperilaku bijak terhadap ilmu yang dituntut. Selaras dengan yang menjadi makna dalam syair Al-'Ilm dan pandangan politik Al-Rasafi, jika ilmu yang kita tuntut semestinya dapat memberi kebermanfaatan untuk sesama.

\section{SIMPULAN}

Terdapat tiga poin penting yang didapat dari proses analisis terhadap syair $\mathrm{Al}$-' $\mathrm{Ilm}$ karya Ma'ruf Al-Rasafi, di antaranya yaitu:

Pembacaan heuristik syair Al-'Ilm menunjukkan jika masih banyak kata atau kalimat yang memiliki heterogenitas makna, mengalami ambiguitas, dan ungramatikal. Secara sekilas, pada pembacaan ini memberikan makna tentang ilmu yang dapat membawa pada kesuksesan dan kemuliaan jika dituntut dengan kesungguhan yang kuat.

Pembacaan hermeneutik dari syair tersebut yaitu mengenai proses menuntut ilmu yang harus dilakukan dengan bersungguh-sungguh, semangat kuat, kesabaran, dan melewati kesusahpayahan sehingga dapat memanfaatkan keilmuannya melalui cara dan jalan yang benar bagi orang-orang di sekitarnya. Adapun matriks atau intisari yang diperoleh yaitu tentang "keutamaan ilmu dan jalan untuk menggapainya", dengan dua model yang diperoleh, yaitu "wa inna lil 'ilmi fì al-'ulā falakān" dan "wa kullu al-ma'āli tadūru fĩ qutubihi” yang masing-masing berarti "ilmu berada tinggi di atas bintang" dan "setiap yang mulia mengeliligi kutubnya". Sedangkan hipogram yang diperoleh berupa hubungan intertekstual dengan potongan bait karya Imam Asy-Syafii, Amru bin Al-Wardi, dan sebuah bait hikmah.

Urgensi ilmu dan akhlak yang sangat kentara dalam syair tersebut menunjukkan jika ilmu dan akhlak merupakan dua hal yang sama-sama memiliki peranan penting

\footnotetext{
33 Yasin T. Al-Jibouri, Two Baghdadi Poets....., hal. 3.
} 
dalam kehidupan. Dapat dilihat dalam pandangan Al-Rasafi, jika ia memiliki harapan terhadap generasi muda sebagai generasi penerus agar memiliki keilmuan dan adab (akhlak) yang dapat membawa manfaat.

\section{DAFTAR PUSTAKA}

Al-Jibouri, Yasin T. Two Baghdadi Poets, One from Rusafa, One from Karkh. (Dar alMa'moon House for Translation and Publication, Iraqi Ministry of Culture, Vol. XXIX). 2013.

Ar-Rashafi, Ma'ruf. Dīwān Ma'rūf Al-Rashāfí. Kairo: Hindawi. 2012.

Khulusi, Safa. Ma'ruf Ar-Rusafi in Jerusalem, (Historical Features). 1993.

Lantowa, Jafar, dkk. Semiotika; Teori, Metode, dan Penerapannya dalam Penelitian Sastra. Yogyakarta: Deepublish. 2017.

Maryana. Ma'na Syi'ru asy-Syaithan wa at-Thilyan Li Ma'ruf ar-Rashafi (Dirasah Simiyaiyyah), (Skripsi, UIN AR-Raniry). 2018.

Pradopo, Rachmat Djoko. Beberapa Teori Sastra, Metode Kritik, dan Penerapannya. Yogyakarta: Pustaka Pelajar. 2012.

-_-. Kamus Al-Ma'ānīy. Diakses pada 6 Februari 2021.

Sumariyanto, Eko Adhi. "Nilai Moral Dalam Novel Al-Ajniḥah Al-Mutakassiroh Karya Kahlil Gibran Dan Memang Jodoh Karya Marah Rusli." Tsaqofiya: Jurnal Pendidikan Bahasa Dan Sastra Arab 2, no. 2 (2020): 84-107.

Taufiq, Wildan. Semiotika untuk Kajian Sastra dan Al-Qur'an. Bandung: Yrama Widya. 2016.

Tim Turos Pustaka. Mahfuzhat (Kumpulan Kata Mutiara Islam-Arab yang Menginspirasi Umat Manusia). Jakarta Selatan: Turos Pustaka. 2018.

Wargadinata, Wildana dan Laily Fitriani. Sastra Arab dan Lintas Budaya. Malang: UIN Malang Press. 2008. 